\title{
Penicillium notatum Antigen IgE Antibody Measurement
}

National Cancer Institute

\section{Source}

National Cancer Institute. Penicillium notatum Antigen IgE Antibody Measurement. NCI

Thesaurus. Code C130146.

A measurement of the Penicillium notatum antigen IgE antibody in a biological specimen. 